MA PETAR S. ĆURČIĆ, istraživač-pripravnik

Institut za evropske studije

Beograd, Republika Srbija

UDK 32 Франк J.:930(497.6)"19/20"

petar.pero.curcic@gmail.com

pregledni $\mathrm{rad} /$ review article

primljeno / received: 27. 5. 2021.

prihvaćeno / accepted: 24. 11. 2021.

https://doi.org/10.29362/ist20veka.2022.1.cur.213-232

\title{
SLIKA JOSIPA FRANKA U HRVATSKOJ ISTORIOGRAFIJI I PUBLICISTICI: PREGLED DOSADAŠNJIH INTERPRETACIJA
}

APSTRAKT: $U$ radu su analizirane interpretacije hrvatske istoriografije i publicistike o Josipu Franku (1844-1911), hrvatskom političaru, pravniku i nacionalnom radniku na prelazu iz 19. u 20. vek. Na osnovu prikazanog uočeno je da o ovom političaru postoji nekoliko istoriografskih predstava. Prva, $i$ svakako najdugovečnija, potekla je od starije hrvatske istoriografije koja je negativno vrednovala Frankovu ulogu u političkom životu. Druga, podjednako dugo prisutna, svesno je, premda iz različitih političkih i ideoloških motiva, zanemarivala Franka. Na kraju, treća, i najrecentnija, afirmativno predstavlja Frankovu ulogu u hrvatskom političkom životu i u današnje vreme ona je dominantna u hrvatskoj istoriografiji.

KLJUČNE REČI: Josip Frank, istoriografija, istoriografska paradigma, interpretacija prošlosti, ideologija

Promena svesti o prošlim događajima predstavlja sastavni deo viševekovne ljudske potrebe da se razume ono što se dogodilo. Međutim, već decenijama se u nauci raspravlja o fenomenu revizionizma i njegovim naučnim implikacijama. ${ }^{1}$ Uvreženo je mišljenje da je revizionizam trend menjanja interpretaci-

\footnotetext{
${ }^{1}$ Lašek Kolakovski, Glavni tokovi marksizma. Tom II (Beograd: BIGZ, 1983), 121-141; Predrag Vranicki, Historija marksizma I (Zagreb: Naprijed, 1971), 228-290; Слободан Јовановић, Из историје политичких доктрина II (Београд: Издавачко и књижарско предузеће Геца Кон А. Д., 1935), 91-101. U istoriografiji, revizionistima se nazivaju i oni naučnici koji su negirali (ili umanjivali) odgovornost Nemačke za dva svetska rata, stradanja Jevreja u Holokaustu itd. Videti: Зоран Малбашић, „Историјски ревизионизам: прогрес науке или идеолошко оружје“, Политичка ревија, XXVIII, vol. 48-2, (2016), 172-173; Davor Marijan, „Suvremena hrvatska povijest i nevolje s revizionizmom“, Ćasopis za suvremenu povijest, LI, br. 2, (2019), 385-420; Mirjana Kasapović, „Povijest, povijesni revizionizam i politike povijesti“, Časopis za suvremenu povijest, LI, br. 3, (2019), 939-960; Davor Marijan, „O znanosti, ideologiji i totalitarnoj svijesti u nedovršenoj hrvatskoj tranziciji - odgovor Mirjani Kasapović“, Ćasopis za suvremenu povijest, LII, br. 1, (2020), 253-292; Peter Štih, „Revizija povijesti i revizionizam u
} 
je prošlosti iz vannaučnih motiva. ${ }^{2}$ Svakako, ovaj pojam ne bi trebalo mešati sa istoriografskom revizijom pređašnjih znanja budući da revizija sa sobom donosi naučnu neutralnost, ozbiljnost i kumulativnost pronalaženjem novih činjenica $i$ reinterpretacijom starih. Takođe, $\mathrm{u}$ istoriografiji i publicistici su, kao i u drugim oblastima, pored onih unutrašnjih okolnosti naučnog razvitka (odnos metoda, činjenica, tumačenja i paradigmi), bitne i opšte društvene i političke okolnosti, kao i ideološke i etičke vrednosti zahvaljujući kojima dostupne činjenice dobijaju puni smisao. U ovom radu cilj je da se - pored pregleda dosadašnjih interpretacija istorijske uloge Josipa Franka u hrvatskoj istoriografiji i publicistici odredi na koji način je vršena (re)interpretacija istoriografske slike o Franku i kakva je međuuslovljenost tih promena sa društvenim kontekstom.

U istoriografiji sećanje na hrvatskog pravnika i političara jevrejskog porekla Josipa Franka (1844-1911) odnosi se pre svega na njegov politički angažman. Frankovo političko delovanje označeno je kao kontroverzno premda nije obavljao nijednu značajnu ulogu u izvršnoj vlasti tadašnje Hrvatske, već je bio prvak i vođa nekoliko opozicionih stranaka (među kojima se posebno ističe Čista stranka prava čiji je formalni i neformalni lider bio od 1895. do 1911. godine). Sa jedne strane, u srpskoj istoriografiji Josip Frank je naročito poznat zbog antisrpske politike i veza prvaka njegove stranke sa potonjim ustaškim pokretom. ${ }^{3}$ Sa druge strane, u hrvatskoj istoriografiji decenijama se vode polemike o njegovoj ulozi u političkom životu.

U godini Frankove smrti 1911. don Kerubin Šegvić, pišući životopis pod nazivom Dr. Ante Starčević - njegov život i njegova djela, ${ }^{4}$ gotovo u potpunosti je zaobišao Starčevićevog bliskog saradnika i naslednika Franka. Doduše, imenom i

historiografiji? Svakako!“, Scrinia Slavonica, XIX, br. 1, (2019), 375-381; Karlo Jurak, „Revizija revizionizma. Prilog raspravi Davora Marijana i Mirjane Kasapović“, Historijski zbornik, LXXIII, br. 1, (2020), 168-178; Janko Bekić, ,'Crni' i 'crveni' u Hrvatskoj i Srbiji“, Političke analize, II, br. 8, (2011), 33-36; Zdenka Janeković Römer, „Problem revizije u povijesnoj znanosti“, u: Historiografija/povijest u suvremenom društvu, urednici Gordan Ravančić, Mislav Gregl, Ivana Horbec, Vlasta Švoger i Dinko Župan (Zagreb: Hrvatski institut za povijest, 2014), 127-136.

2 3. Малбашић, н. д., 169-182; Z. Janeković Römer, n. d., 127-136; Srđan Milošević, „Istorijski revizionizam i društveni kontekst“", u: Politička upotreba prošlosti, urednici: Momir Samardžić, Milivoj Bešlin i Srđan Milošević (Novi Sad: Ako, 2013), 11-26.

${ }^{3}$ Василије Крестић, Историја Срба у Хрватској и Славонији (1848-1914) (Београд: Завод за уџбенике и наставна средства, 1995), 335, 343, 351, 356, 361, 369, 413-414, 416-419, 422, 432, 440, 447, 450, 454, 461, 467, 490-492, 495, 499, 505, 521, 536; Василије Крестић, Геноиидом до Велике Хрватске (Јагодина: Гамбит, 2007), 6, 87, 113, 122, 125, 127, 128, 131, 133, 162; Душан Берић, Хрватско праваштво и Срби II (Нови Сад: Orpheus, 2006), 221-239, 288-317; Дејан Микавица, Српска политика у Хрватској и Славонији: 1538-1918 (Нови Сад: Филозофски факултет, 2015), 118, 233, 240, 267, 270, 273-276, 280, 291-292, $302,304,307,312,316$. Više o genezi ustaškog pokreta i vezama frankovaca sa ustašama videti: Fikreta Jelić-Butić, Ustaše i NDH (Zagreb: SN Liber-Školska knjiga, 1977), 13-22; Cpђa Трифковић, Усташе - балканско срие таме (Београд: Catena mundi, 2016), 33-34, 37-100.

${ }^{4}$ Kerubin Šegvić, Dr. Ante Starčević - njegov život i njegova djela (Zagreb: Tiskara Hrvatske stranke prava, 1911), 263-326. U Srbiji, Jovan Skerlić je izuzetno kritički ocenio Frankovu ulogu u preuzimanju nasleđa Ante Starčevića smatrajući to izvitoperenjem izvorne pravaške slobodarske ideologije: Јован Скерлић, Писии и књиге (Београд: Просвета, 1956), 329-334, 337-343. 
prezimenom Frank je pomenut na legendi jedne fotografije na kojoj su predstavljeni tadašnji hrvatski opozicioni prvaci. ${ }^{5}$ Iako su tokom devedesetih godina 19. veka bili politički bliski, Frank i Šegvić vremenom su postali politički protivnici budući da je Šegvić postao pristalica Mileta Starčevića, sinovca rodonačelnika pravaštva Ante Starčevića i Frankovog oponenta od 1908. godine. Suština izostavljanja Josipa Franka počivala je, dakle, u činjenici da je Šegvić želeo da, u borbi za prestiž među brojnim pravaškim opcijama, istakne Mileta Starčevića kao jedinog ideološkog naslednika Ante Starčevića. Isticanje rivala bilo bi kontraproduktivno, a direktnim napadima slabio bi se potencijal objedinjavanja pravaša koji se od raskola u jedinstvenoj stranci 1895. godine neuspešno planirao.

I po stvaranju Kraljevine SHS/Jugoslavije interesovanje za istoriju pravaštva nije prestajalo. Tako su izdavači Narodne enciklopedije SHS u korpus znanja uključili i ličnosti iz nacionalnih istorija tri vodeća naroda novostvorene države. Pišući o Josipu Franku, istoričar Milan Prelog je, pored kratkih biografskih detalja, izneo i tvrdnju da je Frank bio ,,prividno radikalan, u istini oportunista, uvijek spreman za tajna mešanja s vlastodršcima i neprijateljima našega naroda“. Trajni doprinos Josipa Franka političkom životu Prelog je sagledavao u činjenici da su iza njega ostali antijugoslovenski političari koji su nanosili štetu novoj zemlji. ${ }^{6}$

Ništa manje oštar prema Franku bio je i Miroslav Krleža, tada mladi pisac i opozicioni intelektualac. Želeći da ospori kontinuitet Franka sa Starčevićem, Krleža je smatrao da je Frank odustao od Starčevićeve borbe za hrvatsku samostalnost i slobodu. Zadovoljavajući se isključivo poređenjem ranijih radikalnih Starčevićevih radova i Frankovog potonjeg političkog pragmatizma, Krleža je zanemarivao promenjivost ideje o hrvatskoj samostalnosti kod Ante Starčevića. $^{7}$ Da je Krležino izbacivanje Franka iz glavne linije pravaštva bilo prihvaćeno kod međuratnih komunista svedoči i rad Augusta Cesarca koji je ostao na Krležinim stanovištima. ${ }^{8}$

Tih godina naročito sistematičan $u$ istraživanjima pravaštva bio je istoričar i novinar Josip Horvat. Značajniju pažnju Franku, liberalno orijentisani Hor-

\footnotetext{
${ }^{5}$ K. Šegvić, $n$. d., 312-313.

${ }^{6}$ Milan Prelog, „Frank Josip Dr.“, u: Narodna enciklopedija Srpsko-hrvatsko-slovenačka, I. knjiga A-H (Zagreb: Zaklada tiskare narodnih novina, 1925), 691.

${ }^{7}$ Krležin odnos prema Franku izazivao je oprečna mišljenja u međuratnom periodu. Stanislav Vinaver, srpski pisac jevrejskog porekla, optuživao je Krležu za lažni komunizam i pritajeni „frankovluk“, što je Krleža odbacivao. Videti u: Stanislav Vinaver, „Beograd i g. Krleža“, u: Zli volšebnici. Polemike i pamfleti u srpskoj književnosti 1917-1943. Knjiga prva 1917-1929, urednik Gojko Tešić (Beograd: Slovo ljubve, Beogradska knjiga, 1983), 389-392; Miroslav Krleža, „Mister Vu-San-Pej, zanima se za srpsko-hrvatsko pitanje“, u: Zli volšebnici. Polemike $i$ pamfleti u srpskoj književnosti 1917-1943. Knjiga prva 1917-1929, 397-403; Goran Miloradović, „Miroslav Krleža i pravaštvo. Prilog istoriji ideja i ideologija“, Istorija 20. veka, XXXVII, br. 2, (2019), 29-57; Vaso Bogdanov, „Politička i moralna strana lijeve hajke na Krležu (Odlomci). Idila na sektoru naše lijeve knjige“, u: Zli volšebnici. Polemike i pamfleti u srpskoj književnosti 1917-1943. Knjiga treća 1934-1943, urednik Gojko Tešić (Beograd: Slovo ljubve, Beogradska knjiga, 1983), 789-797.

${ }^{8}$ G. Miloradović, $n$. d., 42-43.
} 
vat posvetio je u svojoj važnoj sintezi novije hrvatske istorije pod nazivom Politička povijest Hrvatske (1936). Sumirajući Frankovu političku delatnost, Horvat je izneo tvrdnje da je Frankova celokupna politika od sedamdesetih godina 19. veka do smrti 1911. predstavljala odustajanje od pređašnje dosledne borbe Ante Starčevića za hrvatsku nezavisnost i slobodu od tuđinske vlasti. Skrivajući se iza izvorne pravaške slobodarske frazeologije, ona se zasnivala na indirektnom propagiranju podređenog položaja Hrvatske i Hrvata prema Beču i Budimpešti. ${ }^{9}$ Tražeći razloge neuspeha Frankove politike, Horvat je naveo da su Franka u konačan politički poraz odveli lična ambicija, nedostatak političkih principa i zamašni oportuni planovi bez realnog utemeljenja u narodu. Takođe, Frank je bio, u Horvatovom tumačenju, vrlo vešt spletkaroš i manipulator koji je ovim sposobnostima uspeo da sujetnog, senilnog i ostarelog Starčevića privuče k sebi zarad realizacije sopstvene austrofilske politike. ${ }^{9}$ I pored ovih negativnih strana, Horvat je u radovima umeo i da istakne snažne crte Frankovog karaktera, naglašavajući da je Frank bio dobar govornik, vešt polemičar i jedan od retkih političara koji se razumeo u finansije i ekonomske odnose u Dvojnoj monarhiji. ${ }^{10}$

I pored činjenice da je ustaški pokret neretko naglašavao svoje veze sa pravaštvom, interesovanje ustaša za Franka - inače direktno rodbinski vezanog za prvake ustaškog režima Slavka i Eugena Dide Kvaternika - nije postojalo. Tako je 1942. godine izašla studija o Anti Starčeviću u izdanju Glavne naklade ustaškog stana u kojoj nije pomenut Frank. ${ }^{11}$ Međutim, Frankovo se ime eksplicitno pominje samo u jednom pismu koje se nalazi u zborniku dela Ante Starčevića, ali taj izvor nije praćen komentarom o Starčevićevom saradniku. ${ }^{12}$ Razlog ovakvom zanemarivanju svakako leži u činjenici da je Frank bio jevrejskog porekla te bi njegovo isticanje u velikoj meri bilo kontraproduktivno po zvaničnu politiku zemlje u kojoj se sprovodila genocidna politika „konačnog rešenja“ jevrejskog pitanja.

Proučavanje pravaštva kao jedinstvenog fenomena intelektualne i političke istorije Hrvata nastavljeno je i nakon Drugog svetskog rata. Sledeći Miroslava Krležu koji je veličao nacionalni rad Ante Starčevića i optuživao Franka za pervertiranje originalne pravaške slobodarske misli, hrvatski istoričar srpskog porekla Vaso Bogdanov je 1951. godine objavio studiju Ante Starčević i Stranka prava prema Srbima i prema jedinstvu južnoslavenskih naroda (1951). U studiji Bogdanov je izjednačio ustaše i frankovce, kako u krivotvorenju originalne Starčevićeve misli, tako i u bespogovornom služenju stranim centrima moći. Za Krležu i Bogdanova, ustaše i frankovci sistematski su pomagali strancima u podjarmljivanju Hrvatske i aktivno su učestvovali u podeli njenih naroda (Srba i

\footnotetext{
${ }^{9}$ Josip Horvat, Politička povijest Hrvatske II (Zagreb: August Cesarec, 1989), 281-283; Јосип Хорват, Странке код Хрвата и њихова идеологија (Београд: Политика, 1939), 61-62; Јоsip Horvat, Ante Starčević - kulturno povijesna slika (Zagreb: A. Velzek, 1940), 380-388; Josip Horvat, Povijest novinstva Hrvatske: 1771-1939 (Zagreb: Stvarnost, 1962), 236-237, 257, 265.

${ }^{10}$ J. Хорват, Странке код Хрвата, 61-62; J. Horvat, Ante Starčević, 380-388.

${ }^{11}$ Ante Starčević (Zagreb: Glavna naklada ustaškog stana, 1942), 5-63.

${ }^{12}$ Ante Starčević, „Dru. Josipu Franku, Sisak 5. 8. 1893.“, u: Ante Starčević, Izabrani spisi, priredio Blaž Jurišić (Zagreb: Hrvatsko izdavalačko bibliografski zavod, 1943), 395-401.
} 
Hrvata) odustajući od originalne Starčevićeve misli o slobodnoj i nezavisnoj Hrvatskoj. ${ }^{13}$ Kao reprezentativan primer frankovačke zloupotrebe Starčevića, Bogdanov je naveo da Starčević pod terminom ,slavoserb“ nije podrazumevao Srbe, za razliku od frankovaca. Ova teza Vase Bogdanova vrlo brzo je osporena, budući da je Mirjana Gros (o kojoj će biti više reči u nastavku) odbacila ove tvrdnje smatrajući da je Starčević tim terminom pejorativno označavao i Srbe. ${ }^{14}$ Posebnost Franka, prema Bogdanovu, počivala je i u tome što je on kao političar bio predvodnik malograđanskih elemenata željnih vlasti, koji su se infiltrirali u Stranku prava i doprineli njenoj transformaciji iz narodne u buržoasku. Ova novina $\mathrm{u}$ tumačenju $^{15} \mathrm{i}$ insistiranje na materijalnim, pre svega ekonomskim i socijalnim, uzrocima društvenih promena bila je, zapravo, posledica nove intelektualne klime proistekle iz marksističke paradigme koja je tih decenija dominirala u jugoslovenskoj istoriografiji. ${ }^{16}$ Takođe, $u$ duhu tadašnje politike pravljenja simetrija između Srba i Hrvata, naglašeno je da su frankovci zloupotrebili Starčevića na isti način kao što su i radikali iz Kraljevine Srbije zloupotrebili Svetozara Markovića. ${ }^{17}$

Realizujući velike projekte, Leksikografski zavod iz Zagreba je u svojim odrednicama o Josipu Franku ostao na istim stanovištima koje su izneli Krleža, Bogdanov i Horvat. Prema njima, Frankova politika ne samo što je bila antisrpska i antijugoslovenska, već je bila u službi stranih centara moći. Pisci odrednica su, koristeći se citatima i parafraziranjem njegovih protivnika (Šenoa i Supilo), iznosili zaključke o nesumnjivom Frankovom političkom talentu i finansijskoj ekspertizi koji su bili pogrešno iskorišćeni u beskrupuloznoj i besplodnoj borbi za vlast. ${ }^{18}$

Pored Vase Bogdanova i Josipa Horvata, tokom šezdesetih godina pravaštvo je počela intenzivno da proučava i Mirjana Gros, poznata hrvatska istoričarka jevrejskog porekla. Oslanjajući se na starije interpretacije Horvata i Bogdanova, Grosova je u nekoliko radova iznela tvrdnje da je cilj Frankove politike bio ne samo prelazak pravaša na kurs dualizma, već i okretanje ove stranke ka interesima malobrojne buržoazije i stranog kapitala umesto dotadašnje zaštite celokupnog naroda. ${ }^{19} \mathrm{I}$ u njenim tumačenjima dominira tendencija da se Frank predstavi

13 Vaso Bogdanov, Starčević i stranka prava prema Srbima i prema jedinstvu južnoslavenskih naroda (Zagreb: Školska knjiga, 1951), 7-9, 17.

${ }^{14}$ Mirjana Gross, Povijest pravaške ideologije (Zagreb: Institut za hrvatsku povijest, 1973), 6, 148; V. Bogdanov, n. d., 10.

15 Tadašnji istoričari su najčešće koristili negativne opise Frana Supila i Augusta Šenoe kako bi potvrdili svoj stav o Franku. Videti: J. Horvat, Povijest novinstva Hrvatske, 236-237, 257, 265; Vaso Bogdanov, Historija političkih stranaka u Hrvatskoj (Zagreb: Novinarsko izdavačko poduzeće, 1958), 760-766; Ivo Petrinović, Politička misao Frana Supila (Split: Književni krug, 1988), 31, 39-41, 57, 61, 65, 74-75, 82, 97-98, 108, 112, 117-118, 122, 145, 227.

${ }^{16}$ Branimir Janković, Mijenjanje sebe same. Prebrazbe hrvatske historiografije kasnog socijalizma (Zagreb: Srednja Europa, 2016), 35-47.

${ }^{17}$ V. Bogdanov, Starčević i stranka prava prema Srbima, 10.

${ }^{18}$ Redakcija E.-J., „Frank, Josip“, u: Enciklopedija Jugoslavije, 3 Dip-Hiđ (Zagreb: Naklada Leksikografskog zavoda FNRJ, 1958), 387; „Frank Josip“, u: Enciklopedija Leksikografskog zavoda, 2 D-Helio (Zagreb: Jugoslavenski leksikografski zavod, 1967), 451.

${ }^{19}$ Mirjana Gross, Vladavina hrvatsko-srpske koalicije (Beograd: Institut društvenih nauka, 1960), 21-22, 37-38. 
kao osoba konstantno lojalna interesima Beča i u nešto manjoj meri Budimpešte. ${ }^{20}$ Tumačeći Frankov pad i Grosova je, slično Horvatu, tvrdila da Frank nije uspeo da ostvari veći uspeh u svojoj politici pre svega zbog nepoverenja kako promađarskih političkih elita Hrvatske, tako i slobodarski okrenutih Hrvata koji su u potpunosti odbijali dualizam. Još jedan razlog Frankove propasti zasnivao se, prema tumačenjima Mirjane Gros, na ozbiljnom nepoverenju svih aktera na političkoj sceni u Frankove sposobnosti, lično poštenje i namere. ${ }^{21}$

Međutim, ne bi trebalo izgubiti iz vida da su Frankovi savremenici izrazito negativno sagledavali i njegovo jevrejsko poreklo. Primera radi, Stjepan Radić je za Josipa Franka pisao da je ,lukavi Žid“, ,židovski sluga“" itd. ${ }^{22}$ Takođe, nezadovoljan saradnjom vojnih vrhova Austro-Ugarske sa Frankom i njegovom strankom, podmaršal Raimund Gerba je u pismu ministru vojnom Dvojne monarhije Francu Ksaveru fon Šenajhu apostrofirao da je Frank pokršteni Jevrejin koga zanima isključivo bogaćenje. ${ }^{23}$ Zanimljivo je na ovom mestu spomenuti da se diskreditacija Franka, isticanjem njegovog nehrvatskog etničkog porekla, nastavila i u godinama postojanja Jugoslavije. Miroslav Krleža je umeo da umesto hrvatskog imena koristi nazive „Herr Joseph Frank“, „Joseph Frank“ i „Jozua Frank“ aludirajući time na strano poreklo i, indirektno, njegove nikad prekinute konfidentske veze sa stranim centrima moći. ${ }^{24}$ Doduše, 1978. godine Krleža je u jednom intervjuu (koji je izdat nekoliko dana pre Frankove godišnjice rođenja) izneo ideju da se kuća Josipa Franka u centru grada obnovi kako bi postala turistička tačka Zagreba. Ovakvim pristupom, ostareli Krleža je pokazao spremnost da se i Frank uvede u kulturu sećanja Zagreba, Hrvatske i Hrvata. ${ }^{25}$ Ovakve reči nekada vrlo oštrog kritičara onoga što se uvredljivo nazivalo „,frankovlukom" moguće je tumačiti i kao izraz novih međunacionalnih kretanja koja su u Hrvatskoj nastupila sa sve otvorenijim zaoštravanjem srpsko-hrvatskih odnosa u poslednjim decenijama postojanja zajedničke federalne države.

Pomenuti zaključci o Franku koje je Grosova ponovila u Povijesti hrvatskog naroda ${ }^{26}$ (1968) i Povijesti pravaške ideologije (1973) nisu naišli na

${ }^{20}$ Mirjana Gross, „Frank, Josip“, u: Enciklopedija Jugoslavije, 4 E-Hrv (Zagreb: Jugoslavenski leksikografski zavod Miroslav Krleža, 1986), 255.

${ }^{21}$ Mirjana Gross, „Geneza Frankove stranke“, Historijski zbornik, XVII, br. 1-4, (1964), 1-16; Mirjana Gross, „Osnovni problemi pravaške politike“, Historijski zbornik, XV, br. 1-4, (1962), 116-118; Mirjana Gross, „Hrvatska politika velikoaustijskog kruga oko prijestolonasljednika Franje Ferdinanda“, Časopis za suvremenu povijest, II, (1970), 16-35. Uporediti: M. Gross, Povijest pravaške ideologije, 197-198, 207, 229, 240, 260-261, 262, 265, 268-270, 271-276, 278, 280-281, 291, 295-296, 299, 301-315, 318-320, 324-325, 332, 338-386.

22 Stjepan Radić, Frankova politička smrt (Izvješće o glavnoj razpravi u tiskovnoj parnici proti uredniku ,Doma“) (Zagreb: Hrvatska pučka seljačka tiskara, 1908), 8-11, 17.

${ }^{23}$ Raimund Gerba, „Abschrift eines Privatbriefes des kommandandierenden Generals in Agram Feldmarschalleutant R. Gerba an Reichskriegminister, 26. Juli 1907.“, u: Iz korespondencije Josipa Franka s Bečom: 1907.-1910, priredili Stjepan Matković i Marko Trogrlić (Zagreb: Hrvatski institut za povijest, Odsjek za povijest Filozofskog fakulteta u Splitu, 2014), 58-67.

${ }^{24} \mathrm{G}$. Miloradović, n. d., 54-55.

${ }^{25}$ Isto, 55.

${ }^{26}$ Jaroslav Šidak, Mirjana Gros, Igor Karaman i Dragovan Šepić, Povijest hrvatskog naroda $g$ 1860-1914 (Zagreb: Školska knjiga, 1968), 130-137, 139-149, 155-160, 209-260. 
apsolutno odobravanje u jugoslovenskoj istoriografiji. Najpre je srpski istoričar Andrija Radenić u tekstu Marginalije na Povijest hrvatskog naroda (1969) kritikovao istraživački pristup pravaštvu stavom da je Mirjana Gros svu odgovornost $u$ pervertiranju pravaške politike prebacila na Franka proizvoljno umanjujući uticaj Ante Starčevića i zanemarujući činjenicu da su frankovci najdosledniji nastavljači nacionalne politike hrvatskih pravaša, te da su doprineli idejnoj afirmaciji potonjih ustaša. Suprotno kritikama, Grosova je odbacila Radenićevu tvrdnju da je Frank jedini idejni naslednik Starčevića smatrajući to pojednostavljivanjem i nerazumevanjem pravaške istorije. ${ }^{27}$

Nakon objavljivanja knjige Istorija Jugoslavije (1972) usledile su velike polemike među jugoslovenskim istoričarima. Tada su naročito oko pojedinih interpretacija iznetih u tom delu polemisali Milorad Ekmečić, jedan od pisaca pomenute sinteze, i Mirjana Gros. I dok je Ekmečić video Franka kao deo jedinstvenog toka pravaške antisrpske politike koja je svoj nastavak dobila u ustaškom pokretu i teroru, Grosova je i ovom autoru zamerila simplifikaciju političkog razvoja modernog pravaštva nakon raskola 1895. godine. Potom, Milorad Ekmečić je smatrao da je Grosova pogrešila što je korene pravaštva tražila u romantizmu i idejama Francuske revolucije, umesto u rasističkim političkim koncepcijama Jožefa Etveša i Artura de Gobinoa. Naime, Ekmečić je tvrdio i da su od velike važnosti u oblikovanju Starčevićevih i Frankovih koncepcija o Srbima kao potomcima robova imale upravo rasističke tvrdnje Gobinoa i Etvešove teze o političkoj naciji kao spoju nejednakih naroda - vladajućih aristokratskih osvajača i podjarmljenih domorodaca. ${ }^{28}$ Premda se polemika vodila godinama, oba autora su ostala na starim tumačenjima. Napuštajući jugoslovensku perspektivu u interpretacijama, Mirjana Gros je to i potvrdila pišući voluminozno delo Izvorno pravaštvo (1998). ${ }^{29}$

${ }^{27}$ Андрија Раденић, „Маргиналије на Повијест хрватског народа“, Историјски гласник, бр. 1-2, (1969), 87-108; Mirjana Gross, „Maliciozne marginalije o 'delikatnim' pitanjima“, Casopis za suvremenu povijest, III, br. 1, (1971), 211-222.

${ }^{28}$ Ivan Božić, Sima Ćirković, Milorad Ekmečić i Vladimir Dedijer, Istorija Jugoslavije (Beograd: Prosveta, 1972), 313, 360, 371, 394; Mirjana Gross, „Ideja jugoslavenstva u XIX st. u Istoriji Jugoslavije“, Časopis za suvremenu povijest, V, br. 2, (1973), 8-21; Milorad Ekmečić, „Odgovor na neke kritike „Istorije Jugoslavije“" (XIX vek)“, Jugoslovenski istorijski časopis, br. 1-2, (1974), 217-281; Mirjana Gross, „Ideja jugoslavenstva u XIX stoljeću i „dogmatski nacionalizam“““, Jugoslovenski istorijski časopis, br. 3-4, (1975), 121-160; Vera Ciliga, „O pogledima Milorada Ekmečića na hrvatsku povijest“, Jugoslovenski istorijski časopis, br. 3-4, (1975), 161-169; Petar Strčić, „Zašto M. Ekmečić nije pobio niti jednu od mojih 49 primjedbi?", Jugoslovenski istorijski časopis, br. 1-2, (1975), 183-184; Mirjana Gross, „U povodu povlačenja Milorada Ekmečića od polemike“, Jugoslovenski istorijski časopis, br. 1-2, (1977), 168-171; Milorad Ekmečić, ,Završna riječ u polemici sa Mirjanom Gros“, Jugoslovenski istorijski časopis, br. 1-2, (1976), 150-156; Коста Николић, Прошлост без историје (Београд: Институт за савремену историју, 2003), 52-67; Милорад Екмечић, Стварағе Југославије II (Београд: Просвета, 1989), 426-427, 500, 568; Милорад Екмечић, Огледи из историје (Београд: Службени лист СРЈ, 1999), 127. Pre Ekmečića, Viktor Novak u delu Magnum crimen iznosi tezu o Starčevićevom i Frankovom rasizmu. Videti: Viktor Novak, Magnum crimen pola vijeka klerikalizma u Hrvatskoj (Zagreb: Nakladni zavod Hrvatske, 1948), 4-5.

${ }^{29}$ Uporediti: Mirjana Gross, Izvorno pravaštvo - ideologija, agitacija i pokret (Zagreb: Golden marketing, 1998), 459, 471, 477-480, 483-484, 499, 504-505, 515, 526, 529, 534, 556, 652, $685,689-691,700-721,727-729,731-765,770-776,778-792,794,795,799-813,816-828$. 
Velike diskusije između predstavnika srpske i hrvatske istoriografije nastavile su se i tokom osamdesetih godina. Raspravljajući sa srpskim istoričarima Franjo Tuđman, istoričar i kasniji hrvatski državnik, poslužio se Frankovim primerom kako bi odbacio teze o velikom uplivu rimokatoličkog klerikalizma u hrvatskoj politici i relativizovao stavove o kontinuitetu genocidne misli u hrvatskoj političkoj misli. Generalizujući stvari, Tuđman je tvrdio da su, pored kosmopolitizma Rimokatoličke crkve, mnogi hrvatski Jevreji (naglašavajući Franka) doprineli postizanju visokog nivoa patriotizma i političke pragmatičnosti koja je uticala na opadanje verskih isključivosti u hrvatskom društvu na prelazu iz 19. u 20. vek. ${ }^{30}$

Padom komunizma i raspadom Jugoslavije nastupile su velike promene $\mathrm{u}$ celokupnom društvu koje su se odrazile i na istoriografiju. U poslednjim godinama rata u Hrvatskoj pojavila su se i nova tumačenja pravaštva. Pišući odvojeno biografske portrete znamenitih pravaša, publicista Nikola Blaž Kalić i akademik HAZU Dubravko Jelčić bili su saglasni u oceni uloge Josipa Franka u pravaškoj istoriji. Po njima, Frank je među prvima prepoznao navodne skrivene namere Kraljevine Srbije o osvajanju Hrvatske. Uz antisrpstvo, centralno mesto u njihovoj reaktuelizaciji i afirmaciji Frankove političke misli zauzima tendencija odbacivanja Jugoslavije kao negativne i silom nametnute tvorevine hrvatskom narodu. Shvaćen u novim okvirima, Frank je postao čovek izuzetnog evropskog obrazovanja, nesumnjivog patriotizma $i$ istančanog realpolitičkog osećaja. ${ }^{31}$ Obojica autora interpretirala su Frankovu proaustrijsku politiku kao izraz težnje da Hrvatska ostane u centralnoevropskom civilizacijskom krugu koji je bio brana savezu sa balkanskom Srbijom. Svakako, proces, manje ili više skrivene, glorifikacije „,srednjoevropske izuzetnosti“ naspram „,balkanskog divljaštva“ deo je šireg intelektualnog pokreta tokom osamdesetih i devedesetih godina 20 . veka koji je detaljno analizirala bugarska istoričarka Marija Todorova. ${ }^{32}$

Nove političke okolnosti zahtevale su i ponovno pokretanje velikih leksikografskih projekata. U obe odrednice napisane za Hrvatski biografski leksikon (1998) i Hrvatsku enciklopediju (2002) unekoliko su ublažena ranija viđenja Josipa Franka. Umesto nekadašnjeg antijugoslovenstva i lažnog opozicionarstva, akcenat je bio stavljen na Frankovu političku promenjivost i spremnost da se kompromisnim rešenjima kroz sistem popravi položaj hrvatskog naroda. ${ }^{33}$

\footnotetext{
${ }^{30}$ Franjo Tuđman, Bespuća povijesne zbiljnosti (Zagreb: Nakladni zavod Matice hrvatske, 1989), $365,376,450-451$

${ }^{31}$ Nikola Blaž Kalić, Život i djela pravaša - dr. Ante Starčević, Mihovil Pavlinović, dr. Josip Frank (Varaždin: Stranka prava, 1994), 41-51, 56-69, 70-84. Na ovom mestu moramo istaći da Nikola Blaž Kalić pored neprimerenog rečnika (upotreba termina „balkanska cigalija“ za Srbiju, str. 66), pokazuje i nepoznavanje činjenica (navodi da je Lenjin predvodnik revolucije 1905. u Rusiji, umesto Vuk Karadžić piše Vuk Karađić, tvrdi da je Majski prevrat u Srbiji 1903. godine organizovao Petar Karađorđević i da su u njemu ubijeni kralj Petar (Sic!) i kraljica Draga). Dubravko Jelčić, Politika i sudbine - eseji, varijacije i glose o hrvatskim političarima (Zagreb: Školska knjiga, 1995), 64-67.

${ }^{32}$ Marija Todorova, Imaginarni Balkan (Beograd: Biblioteka XX vek, 1999), $243-277$.

${ }^{33}$ Mirjana Gross i Mladen Švab, „Frank, Josip“, u: Hrvatski biografski leksikon, 4, E-Gm (Zagreb: Leksikografski zavod Miroslav Krleža, 1998), 383-386; „Frank, Josip“, u: Hrvatska enciklopedija, 4, Fr-Ht, (Zagreb: Leksikografski zavod Miroslav Krleža, 2002), 31.
} 
Ovakvi stavovi najavili su proces detaljne revalorizacije Frankove uloge koja je usledila u hrvatskoj istoriografiji u godinama nakon raspada Jugoslavije. Stjepan Matković, hrvatski istoričar novije generacije, među prvima je detaljno proučavao Frankovo političko delovanje sintetišući postojeća znanja i donoseći nove podatke o stranci i Frankovom ličnom životu. ${ }^{34}$

I u najrecentnijem periodu interesovanje istoričara bilo je usmereno na Frankovu politiku prema Srbima. Proučavajući ovu kompleksnu i kontroverznu temu, Matković je zaključio da je Frank imao promenjivu politiku prema Srbima i da je od zagovornika prava Srba tokom sedamdesetih i osamdesetih godina 19. veka postepeno prešao u negatora njihovog postojanja na teritoriji Hrvatske. Suprotno Starčeviću, Frank je, primećuje Matković, Srbima priznavao posebnost u Srbiji, a tu tezu preuzeće i Matkovićev učenik Mislav Gabelica u svojim radovima ${ }^{35}$ U stvari, frankovačka negacija postojanja Srba u Hrvatskoj zasnivala se na tezi o vlaškom etničkom poreklu prekodrinskih Srba. Naime pravoslavni Vlasi su se posredstvom Srpske pravoslavne crkve i mešanjem sa srpskim migrantima iz Osmanske carevine vremenom posrbili. Iako pominju glavne argumente frankovačke antisrpske politike, oba autora nisu detaljnije kritički vrednovala ove elemente frankovačke politike. Suprotno tome, u srpskoj istoriografiji odavno je odbačena teza o vlaškom poreklu Srba argumentima da se pod terminom Vlah u izvorima od 16. do 18. veka podrazumevala fiskalna grupa, a ne etnička skupina. ${ }^{36}$ Dajući svoju interpretaciju nasilja nad Srbima tokom septembra 1902. godine, u hrvatskoj istoriografiji postoji saglasje da se radi o demonstracijama koje su bile izazvane uvredljivim antihrvatskim tekstom Nikole Stojanovića koji je objavljen u Srbobranu tokom leta 1902. godine. ${ }^{37}$ Višegodišnje polemike između Srbobrana i Hrvatskog prava i antisemitski ispadi usmereni protiv Franka poslužili su, između ostalog, Matkoviću u argumentaciji

${ }^{34}$ Stjepan Matković, Čista stranka prava (1895-1903) (Zagreb: Hrvatski institut za povijest i Dom i svijet, 2001), 12, 14-22, 23-28.

${ }^{35}$ Mislav Gabelica, ,Ideološke razlike između milinovačkih i frankovačkih pravaša uoči Prvoga svjetskog rata (1908.-1914.)“, u: Pravaštvo u hrvatskome političkom i kulturnom životu u sučelju dva stoljeća, urednici Zdravka Jelaska Marijan i Zlatko Matijević (Zagreb: Hrvatski institut za povijest, 2007), 284-302; Mislav Gabelica, „Pravaštvo u Banskoj Hrvatskoj uoči Prvoga svjetskoga rata“ (doktorska disertacija, Sveučilište u Zagrebu, Hrvatski studij, 2012), 40.

${ }^{36}$ S. Matković, Čista stranka prava, 148-160; M. Gabelica, „Pravaštvo u Banskoj Hrvatskoj“, 40; Радослав Грујић, Апологија српског народа у Хрватској и Славонији и његових главних обележија. Поводом „Оптужнице“ кр. држав. одветника у Загребу од 12. I 1909. г. (Нови Сад: Штампарија учитељског деоничар. друштва „Натошевић“, 1909) 7-91; Војин С. Дабић, Војна крајина и Карловачки генералат (1530-1746) (Београд: Свети архијерејски синод Српске православне цркве, 2000), 67-141.

${ }^{37}$ Sličnog stava je i hrvatski istoričar Mato Artuković. Mato Artuković, ,'Srbi i Hrvati' i antisrpske demonstracije 1902. u povijesnoj literaturi i publicistici“, u: Spomenica Filipa Potrebice, urednica Mirjana Matijević Sokol (Zagreb: Odsjek za povijest Filozofskog fakulteta Sveučilišta u Zagrebu - Podružnica za povijest Slavonije, Srijema i Baranje Hrvatskoga instituta za povijest, 2004), 257-292; Mato Artuković, „Pitanje šteta i odštete u antisrpskim demonstracijama 1902. godine“, Časopis za suvremenu povijest, XLII, br. 1, (2010), 179-217. Starija istoriografija bila je mišljenja da su pisanja Srbobrana i frankovačkog Hrvatskog prava bila podjednako izrazito šovinističke prirode. M. Gross, Povijest pravaške ideologije, 268-281, 311-320. 
teze da je ,...trend srpske narodne afirmacije pratila i sve oštrija konkurencija prema drugim skupinama, bilo da je riječ o manjinama ili o Hrvatima“" ${ }^{38}$ Znatno pojednostavljajući fenomen antisemitizma u Hrvatskoj, Mato Artuković je, suprotno Matkoviću, istakao da je Josip Frank primer ne samo antisemitske politike Srbobrana, već i nepostojanja kontinuiteta antisemitizma u hrvatskom narodu i pravaškoj misli budući da je pravaštvo, pogotovo ono frankovačkog tipa, bilo inkluzivno prema nekatolicima svih veroispovesti. ${ }^{39}$

Takođe, tumačenja o „,buržoaskom“ i „konjunkturističkom“ karakteru Frankove politike su napuštena, a počela je da se naglašava Frankova borba za radnička prava i njegova popularnost u tom društvenom sloju. ${ }^{40}$ Novim situiranjem Frankove stranke u političkom životu savremena hrvatska istoriografija je - priznajući toj političkoj opciji opozicioni status - odbacila ranije tvrdnje o lažnom opozicionarstvu. I Frankova politička karijera u opoziciji pre ulaska u Stranku prava 1890. godine počela je znatno pozitivnije da se vrednuje. Jasna Turkalj je iznela zaključak da je Frankova politika tokom osamdesetih godina 19. veka bila proaktivna i posrednička u sukobima između vlasti i progonjene pravaške opozicije. Razloge za pristupanje pravašima Turkalj je našla u pritiscima režima, solidarnosti između opozicionara, Frankovom prihvatanju koncepta hrvatskog državnog prava i želji da se pravaška stranka reformiše i učini umerenom opozicijom dualističkom režimu. ${ }^{41} \mathrm{U}$ novim vremenima razlozi za nemogućnost objedinjavanja nekadašnje opozicije na prelazu iz 19. u 20. vek tražili su se u neslaganjima svih političkih lidera, a ne u osuđivanju frankovačke strane kao što je to bio slučaj ranije. Pored Radićevog antisemitizma, hrvatska istoriografija počela je da preispituje i stavove Frana Supila. Posebno je hrvatski istoričar i filozof Jure Krišto zamerao generaciji starijih istoričara (poput Horvata, Bogdanova, Gros i Stančića ${ }^{42}$ ) glorifikaciju Supila i diskreditaciju Franka. Sledeći stanovišta o odbacivanju celokupnog jugoslovenskog projekta, i Krišto

${ }^{38}$ S. Matković, Čista stranka prava, 142.

${ }^{39}$ Mato Artuković, Ideologija srpsko-hrvatskih sporova (Srbobran 1884-1902) (Zagreb: Naprijed, 1991), 102.

40 J. Horvat, Politička povijest, 222-269; Vaso Bogdanov, „Hrvatski narodni pokret 1903/4.”, Rad $J A Z U$, br. 321, (1960), 225-478; Vaso Bogdanov, „Hrvatski narodni pokret 1903/4.”, Rad JA$Z U$, br. 322, (1961), 5-144. Stjepan Matković, „Politički odnosi Josipa Franka i frankovaca prema radićevskoj ideologiji“, Radovi - Zavod za hrvatsku povijest, XXXII-XXXIII, br. 1, (2000), 277-282; Stjepan Matković, Izabrani portreti pravaša (Zagreb: Hrvatski institut za povijest, 2011), 89-93; Ivo Goldstein, „Stjepan Radić i Židovi“, Radovi-Zavod za hrvatsku povijest, XXIX, br. 1, (1996), 209-210; Branka Boban, „Ivan Peršić o Stjepanu Radiću: u povodu knjige Kroničarskih spisa Ivana Peršića“, Časopis za suvremenu povijest, XXXV, br. 1, (2003), 262, 268, 272, 280; Stjepan Matković, „Politički odnosi Josipa Franka i frankovaca prema radićevskoj ideologiji“, Radovi - Zavod za hrvatsku povijest, XXXII-XXXIII, br. 1, (2000), 277282; M. Gross, Povijest pravaške ideologije, 303-309; S. Matković, Čista stranka prava, 225241; Stjepan Matković, „Stranka prava i hrvatski kršćanski socijali“, u: Hrvatski katolički pokret, urednik Zlatko Matijević (Zagreb: Kršćanska sadašnjost, 2002), 321-327.

${ }^{41}$ Jasna Turkalj, Pravaški pokret 1878.-1887. (Zagreb: Hrvatski institut za povijest, 2009), 360363, 367, 389-390, 430-431.

${ }^{42}$ Radi se o kratkom sumiranju pređašnjih istraživanja. Nikša Stančić, Hrvatska nacija i nacionalizam u 19. i 20. stoljeću (Zagreb: Barbat, 2002), 126. 
je pozitivno vrednovao Frankovu antijugoslovensku i probečku politiku iz perspektive naknadnih događaja raspada Jugoslavije iznoseći tvrdnju da je Frankova probečka politika bila manje sporna od Supilove prosrpske. ${ }^{43}$

Naravno, u novim vremenima prestalo se i sa tumačenjima o Frankovom „kolaboracionizmu“ i izvitoperenju izvorne Starčevićeve ideologije, a istoričari su počeli da ističu političke i programske razlike među političarima afirmišući na taj način Frankov patriotizam i liberalizam. ${ }^{44}$ Kao posebno sporno, i iznova aktuelno, isticalo se pitanje odnosa Josipa Franka prema vrhovima Dvojne monarhije. Shvaćen više ne kao puki izvršilac volje vrhova Habzburške monarhije, Franku su priznate patriotske pobude i isticana je dosledna upornost u pregovorima sa Bečom, Budimpeštom i tadašnjim banom Rauhom. Savremena istoriografija naglašavala je i činjenicu da je Frank, i pored spremnosti da $u$ dogovoru sa sistemom traži kreativna rešenja za stvaranje Velike Hrvatske u okvirima Austro-Ugarske, izneveren i napušten od centara moći. ${ }^{45} \mathrm{Za}$ novu generaciju istoričara Frank je, zapravo, bio vešt realan političar koji je težio da postepenim promenama (Velikoj) Hrvatskoj obezbedi poseban status u Habzburškoj monarhiji. ${ }^{46}$ Antisrpski karakter frankovačke agitacije tokom Aneksione krize i Veleizdajničkog procesa protiv Srba u Zagrebu, pojedini hrvatski istoričari su pokušali da relativizuju raznim tvrdnjama. Pored naglašavanja antihabzburškog karaktera srpske politike u Hrvatskoj i Srbiji (za koju je zaključeno da je bila tolerisana od Beča), u hrvatskoj istoriografiji postoji i spremnost da se opravda postojanje frankovačkih legija mišljenjem da su one nastale kao odgovor pristalica Frankove stranke na naoružavanje dobrovoljačkih jedinica u Kraljevini Srbiji. ${ }^{47}$ Prema Mislavu Gabelici, i druge političke organizacije (pre svih socijaldemokrate i pristalice Mileta Starčevića) imale su svoje paramilitarne grupacije. Njihovi sukobi (a ne isključivost i nasilnost frankovačke strane), bili

${ }^{43}$ Jure Krišto, „Sukobi Franka i Supila i problematično historiografsko nasleđe o njima“, Kroatologija, II, br. 1, (2011), 79-91; Jure Krišto, „Kad pravaši pođu različitim putovima: Supilo i Frank“, u: Pravaška misao i politika, urednici Jasna Turkalj, Zlatko Matijević i Stjepan Matković (Zagreb: Hrvatski institut za povijest, 2007), 145-164; Jure Krišto, Prešućena povijest: katolička crkva u hrvatskoj politici: 1850.-1918 (Zagreb: Hrvatska sveučilišna naklada, 1994), 116, 118, 141-144, 190, 215, 217, 222, 248, 250, 260-261, 277, 279, 291, 296-297, 299, 300, 332.

${ }^{44}$ Stjepan Matković, „Prezreni pravaš - u prigodi 100. godišnjice smrti dr. Josipa Franka“, Pilar, XII, br. 2, (2011), 165-174; Stjepan Matković, „Josip Frank i kritika financijskog dijela Hrvatsko-ugarske nagodbe“, Pilar, XI, br. 1, (2011), 27-34. Sličnih stavova o modernosti Frankove politike je i Mira Kolar Dimitrijević. Mira Kolar-Dimitrijević, „Jedan pogled na gospodarsku aktivnost pravaških vođa od 1861. do 1914. godine“, u: Pravaška misao i politika, 113-114, $115-120$.

${ }^{45}$ Marko Trogrlić, „Hrvatska i „hrvatsko pitanje“ u korespondenciji Josipa Franka i Moritza von Auffenberg-Komarowa (1908.-1910.)“, u: Pravaška misao i politika, 168-180; M. Gabelica, „Pravaštvo u Banskoj Hrvatskoj“, 48-54.

${ }^{46}$ Mislav Gabelica, „Ideološke razlike između milinovačkih i frankovačkih pravaša“, 284-302.

${ }^{47}$ M. Gabelica, ,Pravaštvo u Banskoj Hrvatskoj“", 40; Mislav Gabelica, ,„,Borbenost“" u politici Čiste stranke prava (Starčevićeve hrvatske stranke prava / Stranke prava)“, Pilar, vol. XIV, no. 27-28, (1-2) (2019), 92; Mira Kolar-Dimitrijević, „Ban Pavle Rauch i Hrvatska u njegovo vrijeme“, Povijesni prilozi, vol. 18, br. 18, (1999), 248, 262-267; Mislav Gabelica, „Zagrebačka veleizdajnička parnica 1909. godine“, Časopis za suvremenu povijest, XLVI, br. 1 (2014), 131-156. 
su deo političke borbe u Hrvatskoj početkom 20. veka što predstavlja novinu u tumačenju i napuštanje pređašnjih izrazito antifrankovačkih stavova o hrvatskim legijama $\mathrm{u}$ istoriografiji. ${ }^{48}$

Grupa savremenih hrvatskih istoričara koji proučavaju fenomen pravaštva saglasna je u oceni da je Frankova verska politika bila liberalna i inkluzivna prema muslimanima, Jevrejima i pravoslavcima. Čak ni u sjedinjenju između frankovaca, viđenih kao pristalica verskih sloboda, i rimokatoličkih klerikalaca, istoričari nisu videli izraz idejne klerikalizacije, već praktične težnje da se opstane u političkom životu. Shvaćen realpolitički, Frank je stupio u bliske veze sa strankom Hrišćanskih socijalista bečkog gradonačelnika Karla Ligera kako bi stekao političkog, a ne idejnog, saveznika u borbi za hrvatske interese. ${ }^{49}$

Veza ustaša i frankovaca delimično je obrađena u hrvatskoj istoriografi$\mathrm{ji}^{50}$ a hrvatski istoričari mahom su odbacivali ideje o povezanosti dva pokreta. Posmatrajući genezu rasne ideje u ustaškom pokretu, Nevenko Bartulin odbacio je uzročno-posledičnu povezanost Frankovog građanskog nacionalizma sa ustaškim nacionalizmom, a istakao je i da Frank nije bio u potpunosti uvažavan među ustaškim prvacima zbog jevrejskog porekla. ${ }^{51}$

Duže od jednog veka u hrvatskoj istoriografiji i publicistici slika o Josipu Franku vrlo je polarizovana. Ipak, mnogo oštriji bili su kritičari Frankovog lika i dela. Njih je najviše bilo u vremenu postojanja Jugoslavije i negativno predstavljanje delovanja ovog hrvatskog političara povezano je sa izrazitom antisrpskom i antijugoslovenskom ideologijom frankovačkog pokreta. Doduše, Frankovo političko delovanje takođe je nerazdvojno i od Ante Starčevića i istorije pravaškog pokreta. U vremenima kada se gradila ulepšana slika geneze jugoslovenske države u istoriografiji, Anti Starčeviću, viđenom tada kao velikom borcu za jugoslovensko jedinstvo, suprotstavljan je Josip Frank. Svaćen kao predstavnik kolaboracionizma u večitoj borbi između slobodarstva i poslušništva jugoslovenskih naroda, na Franka je prebačena odgovornost za antisrpstvo, podanički odnos prema stranim centrima moći (u ovom slučaju Beču i

\footnotetext{
${ }^{48}$ M. Gabelica, „,,Borbenost“" u politici Čiste stranke prava“, 102-107.

49 Zlatko Hasanbegović, „Islam i muslimani u pravaškoj ideologiji: o pokušaju gradnje „pravaške“ džamije u Zagrebu“, u: Pravaška misao i politika, 91-96; Jure Krišto, „Hrvatski propali pokušaji s kršćanskim socijalizmom", u: Pravaštvo u hrvatskome političkom i kulturnom životu u sučelju dva stoljeća, 156-165; Mario Strecha, Katoličko pravaštvo: politički katolicizam u Banskoj Hrvatskoj u predvečerje Prvoga svjetskog rata: (1904-1910) (Zagreb: Srednja Europa, 2011), 21, 30-35, 49-50, 58, 72-73, 77, 91, 124, 128, 148, 150-151, 155, 190-191, 197, 238, $250,257,266,290,292,296,300-301,306-307,310-311,317-323,325,327-329,333-337$, 344-345, 355-356, 361, 363.

${ }^{50}$ S. Matković, Čista stranka prava, 306-341.

${ }^{51}$ Nevenko Bartulin, The Racial Idea in the Independent State of Croatia (Leiden-Boston: Brill, 2014), 39, 68, 129, 132, 155-156; Nevenko Bartulin, „From Independence to Trialism: The Croatian Party of Right and the Project for a Liberal "Greater Croatia“ within the Habsburg Empire, 1861-1914“", u: Liberal Imperialism in Europe, urednik Matthew P. Fitzpatrick (New York: Palgrave Macmillan, 2012), 116-134.
} 
Budimpešti) i oblikovanje budućeg ustaškog pokreta. Rehabilitujući i otvoreno slaveći slobodarstvo i jugoslovenstvo Starčevića, hrvatski istoričari i intelektualci (pre svih Milan Prelog, Josip Horvat, Mirjana Gros i posebno Miroslav Krleža) u obe Jugoslavije su, manje ili više, prenebregavali idejne kontinuitete između Starčevića i Franka. Zapravo, Frank je iz nekoliko razloga bio veoma pogodna ličnost za kasniju istoriografsku diskreditaciju. Pratile su ga brojne afere i politički neuspesi, imao je mnogo političkih protivnika, a njegovo nehrvatsko poreklo poslužilo je pojedinim intelektualcima (pre svega Krleži) u njegovoj post mortem difamaciji.

U srpskoj istoriografiji javio se snažan otpor odvajanju Starčevića i Franka. Tražeći duboke kontinuitete unutar hrvatskog nacionalizma, srpski istoričari su neretko kao crvenu nit hrvatske nacionalističke politike isticali antisrpstvo hrvatskih pravaša (naročito Starčevića i Franka). Sukob dve nacionalne istoriografije u pogledu tumačenja pravaške istorije kulminirao je po objavljivanju Istorije Jugoslavije grupe srpskih autora početkom sedamdesetih godina 20 . veka. U vremenu nakon gušenja Maspoka, naročito oštre bile su dugogodišnje polemike između Mirjane Gros i Milorada Ekmečića, a gotovo pedeset godina od okončanja ovog sukoba istoričara može se reći da su radikalne promene u sagledavanju Frankove uloge nastupile samo u hrvatskoj istoriografiji. Srpska istoriografija nastavila je, pak, da pravaše, pogotovo one frankovačke, posmatra pre svega kroz prizmu njihove antisrpske politike i kasnijih veza sa ustaškim pokretom.

Gotovo proročki najavljujući povratak Franka u polje kulture sećanja Zagreba, Hrvatske i Hrvata, Miroslav Krleža je anticipirao novo doba. Slomom Jugoslavije, ratom u Hrvatskoj i sukobom između Srba i Hrvata, stvorene su nove mogućnosti i okviri da se revalorizuje istorijska uloga Josipa Franka. Nekadašnja tumačenja koja su pisana sa izrazito antifrankovačkih pozicija, gotovo su utihnula. Umesto njih, istoriografija u novoj, samostalnoj hrvatskoj državi bila je sklona da znatno blaže i afirmativnije vrednuje Frankovo političko delovanje. U novim tumačenjima, autori nisu diskvalifikovali Franka kao izdajnika nacionalnih interesa i lažnog opozicionara čije je političko delovanje vezano za puko izvršavanje naređenja Beča i Budimpešte. Naprotiv, Franka su u savremenoj istoriografiji počeli da smatraju revnosnim i oštrim opozicionarom, spremnim da kroz politiku realističkog prilagođavanja postepeno popravlja položaj hrvatskog naroda u Habzburškoj monarhiji. Ne samo da je antijugoslovenstvo prestalo da mu se zamera u vremenu kada se kultura sećanja gradi na oštroj kritici celokupnog jugoslovenskog projekta, već se i o Frankovom antisrpstvu više ne piše sa nekadašnjih kritičkih pozicija. Pojedini istoričari spremni su i da opravdaju antisrpsko stanovište smatrajući da je Frank jedan od simbola hrvatske odbrane protiv tzv. velikosrpske ideje. Kod pojedinih autora, Centralna Evropa, Beč i Budimpešta viđeni su i kao pozitivan, zapadni i centralnoevropski pandan negativnoj i balkanskoj Srbiji i Jugoslaviji. Još od uzgrednog spominjanja Franka u radu Franje Tuđmana, u istoriografiji savremene Hrvatske postoji težnja da se Frank predstavi kao moderan, liberalan, verski tolerantan i pragmatičan političar. Međutim, i pored ovakvih trendova, Josip Frank u hrvatskoj javnosti i kulturni sećanja nije dobio odgovara- 
juće mesto o čemu svedoči činjenica da ne postoji nijedna njegova ulica ili trg u bilo kojem većem gradu u Hrvatskoj.

Slučaj istoriografske interpretacije Josipa Franka gotovo je školski primer kako se tumačenja menjaju sa promenama vladajućih naučnih paradigmi, ideologija i političkih sistema. Dosadašnja, i moguća buduća, motivacija za vrednovanje, a potom i prevrednovanje, političke uloge ovog kontroverznog hrvatskog političara svakako je i posledica novih političkih stremljenja, ali i drugačijih naučnih tumačenja raspoloživih izvora.

\section{REFERENCE}

- Ante Starčević. Zagreb: Glavna naklada ustaškog stana, 1942.

- Artuković, Mato. „'Srbi i Hrvati' i antisrpske demonstracije 1902. u povijesnoj literaturi i publicistici“. U: Spomenica Filipa Potrebice. Urednica Mirjana Matijević Sokol, 257-292. Zagreb: Odsjek za povijest Filozofskog fakulteta Sveučilišta u Zagrebu - Podružnica za povijest Slavonije, Srijema i Baranje Hrvatskoga instituta za povijest, 2004.

- Artuković, Mato. „Pitanje šteta i odštete u antisrpskim demonstracijama 1902. godine“. Časopis za suvremenu povijest, XLII, br. 1, (2010), 179-217.

- Artuković, Mato. Ideologija srpsko-hrvatskih sporova (Srbobran 1884-1902). Zagreb: Naprijed, 1991.

- Bartulin, Nevenko. "From Independence to Trialism: The Croatian Party of Right and the Project for a Liberal „Greater Croatia“ within the Habsburg Empire, 1861-1914”. In: Liberal Imperialism in Europe. Editor Matthew P. Fitzpatrick, 116-134. New York: Palgrave Macmillan, 2012. https://doi.org/10.1057/9781137019974_6

- Bartulin, Nevenko. The Racial Idea in the Independent State of Croatia. Leiden-Boston: Brill, 2014. https://doi.org/10.1163/9789004262829

- Bekić, Janko. „„,Crni““ i „,crveni“ u Hrvatskoj i Srbiji“. Političke analize, II, br. 8, (2011), 33-36.

- Berić, Dušan. Hrvatsko pravaštvo i Srbi II. Novi Sad: Orpheus, 2006.

- Boban, Branka. „Ivan Peršić o Stjepanu Radiću: u povodu knjige Kroničarskih spisa Ivana Peršića“. Časopis za suvremenu povijest, XXXV, br. 1, (2003), 261-284.

- Bogdanov, Vaso. „Starčevićeva stranka prava prema oslobođenju i ujedinjenju južnoslavenskih naroda u toku Prvog svjetskog rata“. U: Jugoslavenski odbor u Londonu. Urednici Vaso Bogdanov, Ferdo Čulinović i Marko Kostrenčić, 27-163. Zagreb: Jugoslavenska akademija znanosti i umjetnosti, 1966.

- Bogdanov, Vaso. „Hrvatski narodni pokret 1903/4.”. Rad JAZU, br. 321, (1960), 225-478.

- Bogdanov, Vaso. „Hrvatski narodni pokret 1903/4.”. Rad JAZU, br. 322, (1961), 5-144.

- Bogdanov, Vaso. „Politička i moralna strana lijeve hajke na Krležu (Odlomci). Idila na sektoru naše lijeve knjige“. U: Zli volšebnici. Polemike i pamfleti u 
srpskoj književnosti 1917-1943. Knjiga treća 1934-1943. Urednik Gojko Tešić, 789-797. Beograd: Slovo ljubve, Beogradska knjiga, 1983.

- Bogdanov, Vaso. Historija političkih stranaka u Hrvatskoj. Zagreb: Novinarsko izdavačko poduzeće, 1958.

- Bogdanov, Vaso. Starčević i stranka prava prema Srbima i prema jedinstvu južnoslavenskih naroda. Zagreb: Školska knjiga, 1951.

- Božić Ivan, Sima Ćirković, Milorad Ekmečić i Vladimir Dedijer. Istorija Jugoslavije. Beograd: Prosveta, 1972.

- Ciliga, Vera. „O pogledima Milorada Ekmečića na hrvatsku povijest““. Jugoslovenski istorijski časopis, br. 3-4, (1975), 161-169.

- Dabić, Vojin. Vojna krajina i Karlovački generalat (1530-1746). Beograd: Sveti arhijerejski sinod Srpske pravoslavne crkve, 2000.

- Ekmečić, Milorad. „Odgovor na neke kritike „Istorije Jugoslavije“ (XIX vek)“. Jugoslovenski istorijski časopis, br. 1-2, (1974), 217-281.

- Ekmečić, Milorad. „Završna riječ u polemici sa Mirjanom Gros“. Jugoslovenski istorijski časopis, br. 1-2, (1976), 150-156.

- Ekmečić, Milorad. Ogledi iz istorije. Beograd: Službeni list SRJ, 1999.

- Ekmečić, Milorad. Stvaranje Jugoslavije II. Beograd: Prosveta, 1989.

- Enciklopedija Jugoslavije, Redakcija. „Frank, Josip“. U: Enciklopedija Jugoslavije, 3, Dip-Hiđ, 387. Zagreb: Naklada Leksikografskog zavoda FNRJ, 1958.

- „Frank Josip“, U: Enciklopedija Leksikografskog zavoda, 2, D-Helio, 451. Zagreb: Jugoslavenski leksikografski zavod, 1967.

- „Frank, Josip“. U: Hrvatska enciklopedija, 4, Fr-Ht, 31. Zagreb: Leksikografski zavod Miroslav Krleža, 2002.

- Gabelica, Mislav. „„,Borbenost“ u politici Čiste stranke prava (Starčevićeve hrvatske stranke prava / Stranke prava)“. Pilar, vol. XIV, no. 27-28, (1-2), (2019), 75-114.

- Gabelica, Mislav. „Ideološke razlike između milinovačkih i frankovačkih pravaša uoči Prvoga svjetskog rata (1908.-1914.)“. U: Pravaštvo u hrvatskome političkom i kulturnom životu u sučelju dva stoljeća. Urednici Zdravka Jelaska Marijan i Zlatko Matijević, 283-304. Zagreb: Hrvatski institut za povijest, 2007.

- Gabelica, Mislav. „Pravaštvo u Banskoj Hrvatskoj uoči Prvoga svjetskoga rata“. Doktorska disertacija, Sveučilište u Zagrebu, Hrvatski studij, 2012.

- Gabelica, Mislav. „Zagrebačka veleizdajnička parnica 1909. godine“. Časopis za suvremenu povijest, vol. XLVI, br. 1, (2014), 131-157.

- Gerba, Raimund. „Abschrift eines Privatbriefes des kommandandierenden Generals in Agram Feldmarschalleutant R. Gerba an Reichskriegminister, 26. Juli 1907.“ U: Iz korespondencije Josipa Franka s Bečom: 1907.-1910. Priredili Stjepan Matković, Marko Trogrlić, 58-67. Zagreb: Hrvatski institut za povijest, Odsjek za povijest Filozofskog fakulteta u Splitu, 2014.

- Goldstein, Ivo. „Stjepan Radić i Židovi“. Radovi-Zavod za hrvatsku povijest, XXIX, br. 1, (1996), 208-216.

- Gross Mirjana, i Mladen Švab. „Frank, Josip“. U: Hrvatski biografski leksikon, 4, E-Gm, 383-386. Zagreb: Leksikografski zavod Miroslav Krleža, 1998. 
- Gross, Mirjana. „Geneza Frankove stranke“. Historijski zbornik, XVII, br. 14, (1964), 1-83.

- Gross, Mirjana. „Frank, Josip“. U: Enciklopedija Jugoslavije, 4, E-Hrv, 255. Zagreb: Jugoslavenski leksikografski zavod Miroslav Krleža, 1986.

- Gross, Mirjana. „Hrvatska politika velikoaustijskog kruga oko prijestolonasljednika Franje Ferdinanda“. Časopis za suvremenu povijest, II, (1970), 9-72.

- Gross, Mirjana. „Ideja jugoslavenstva u XIX st. u Istoriji Jugoslavije“. Časopis za suvremenu povijest, V, br. 2, (1973), 8-21.

- Gross, Mirjana. „Ideja jugoslavenstva u XIX stoljeću i „dogmatski nacionalizam“. Jugoslovenski istorijski časopis, br. 3-4, (1975), 121-160.

- Gross, Mirjana. „Maliciozne marginalije o 'delikatnim’ pitanjima“. Časopis za suvremenu povijest, III, br. 1, (1971), 211-222.

- Gross, Mirjana. „Osnovni problemi pravaške politike“. Historijski zbornik, XV, br. 1-4, (1962), 61-120.

- Gross, Mirjana. „U povodu povlačenja Milorada Ekmečića od polemike“. Jugoslovenski istorijski časopis, br. 1-2, (1977), 168-171.

- Gross, Mirjana. Izvorno pravaštvo - ideologija, agitacija i pokret. Zagreb: Golden marketing, 1998.

- Gross, Mirjana. Povijest pravaške ideologije. Zagreb: Institut za hrvatsku povijest, 1973.

- Gross, Mirjana. Vladavina hrvatsko-srpske koalicije. Beograd: Institut društvenih nauka, 1960.

- Grujić, Radoslav. Apologija srpskog naroda u Hrvatskoj i Slavoniji i njegovih glavnih obeležija. Povodom „Optužnice“ kr. držav. odvetnika u Zagrebu od 12. I 1909. g. Novi Sad: Štamparija učiteljskog deoničar. društva „Natošević“،, 1909.

- Hasanbegović, Zlatko. „Islam i muslimani u pravaškoj ideologiji: o pokušaju gradnje ,pravaške“ džamije u Zagrebu“. U: Pravaška misao i politika. Urednici Jasna Turkalj, Zlatko Matijević, Stjepan Matković, 87-96. Zagreb: Hrvatski institut za povijest, 2007.

- Horvat, Josip. Ante Starčević - kulturno povijesna slika. Zagreb: A. Velzek, 1940.

- Horvat, Josip. Politička povijest Hrvatske II. Zagreb: August Cesarec, 1989.

- Horvat, Josip. Povijest novinstva Hrvatske: 1771-1939. Zagreb: Stvarnost, 1962.

- Horvat, Josip. Stranke kod Hrvata i njihova ideologija. Beograd: Politika A. D., 1939.

- Janeković Römer, Zdenka. „Problem revizije u povijesnoj znanosti“. U: Historiografija/povijest u suvremenom društvu. Urednici Gordan Ravančić, Mislav Gregl, Ivana Horbec, Vlasta Švoger i Dinko Župan, 127-136. Zagreb: Hrvatski institut za povijest, 2014.

- Janković, Branimir. Mijenjanje sebe same. Prebrazbe hrvatske historiografije kasnog socijalizma. Zagreb: Srednja Europa, 2016.

- Jelčić, Dubravko. Politika i sudbine - eseji, varijacije i glose o hrvatskim političarima. Zagreb: Školska knjiga, 1995.

- Jelić-Butić, Fikreta. Ustaše i NDH. Zagreb: SN Liber-Školska knjiga, 1977. 
- Jovanović, Slobodan. Iz istorije političkih doktrina II. Beograd: Izdavačko i knjižarsko preduzeće Geca Kon A. D., 1935.

- Jurak, Karlo. „Revizija revizionizma. Prilog raspravi Davora Marijana i Mirjane Kasapović". Historijski zbornik, LXXIII, br. 1, (2020), 168-178.

- Kalić, Nikola Blaž. Život i djela pravaša - dr. Ante Starčević, Mihovil Pavlinović, dr. Josip Frank. Varaždin: Stranka prava, 1994.

- Kasapović, Mirjana. „Povijest, povijesni revizionizam i politike povijesti“. Ćasopis za suvremenu povijest, LI, br. 3, (2019), 939-960.

- Kolakovski, Lašek. Glavni tokovi marksizma. Tom II. Beograd: BIGZ, 1983.

- Kolar-Dimitrijević, Mira. „Ban Pavle Rauch i Hrvatska u njegovo vrijeme“. Povijesni prilozi, vol. 18, br. 18, (1999), 241-323.

- Kolar-Dimitrijević, Mira. „Jedan pogled na gospodarsku aktivnost pravaških vođa od 1861. do 1914. godine“. U: Pravaška misao i politika. Urednici Jasna Turkalj, Zlatko Matijević, Stjepan Matković, 97-124. Zagreb: Hrvatski institut za povijest, 2007.

- Krestić, Vasilije. Genocidom do Velike Hrvatske. Jagodina: Gambit, 2007.

- Krestić, Vasilije. Istorija Srba u Hrvatskoj i Slavoniji (1848-1914). Beograd: Zavod za udžbenike i nastavna sredstva, 1995.

- Krišto, Jure. „Kad pravaši pođu različitim putovima: Supilo i Frank“. U: Pravaška misao i politika. Urednici Jasna Turkalj, Zlatko Matijević, Stjepan Matković, 143-166. Zagreb: Hrvatski institut za povijest, 2007.

- Krišto, Jure. „Sukobi Franka i Supila i problematično historiografsko nasleđe o njima“. Kroatologija, II, br. 1, (2011), 79-94.

- Krišto, Jure. Prešućena povijest: katolička crkva u hrvatskoj politici: 1850.1918. Zagreb: Hrvatska sveučilišna naklada, 1994.

- Krleža, Miroslav. „Mister Vu-San-Pej, zanima se za srpsko-hrvatsko pitanje“. U: Zli volšebnici. Polemike i pamfleti u srpskoj književnosti 1917-1943. Knjiga prva 1917-1929. Urednik Gojko Tešić, 397-403. Beograd: Slovo ljubve, Beogradska knjiga, 1983.

- Malbašić, Zoran. „Istorijski revizionizam: progres nauke ili ideološko oružje“. Politička revija, XXVIII, vol. 48, br. 2, (2016), 169-185.

https://doi.org/10.22182/pr.4822016.9

- Marijan, Davor. „O znanosti, ideologiji i totalitarnoj svijesti u nedovršenoj hrvatskoj tranziciji - odgovor Mirjani Kasapović". Časopis za suvremenu povijest, LII, br. 1, (2020), 253-292.

- Marijan, Davor. „Suvremena hrvatska povijest i nevolje s revizionizmom“. Časopis za suvremenu povijest, LI, br. 2, (2019), 385-420.

https://doi.org/10.22586/csp.v51i2.9120

- Matković, Stjepan. „Josip Frank i kritika financijskog dijela Hrvatsko-ugarske nagodbe“. Pilar, XI, br. 1, (2011), 191-198.

- Matković, Stjepan. „Političke borbe i prijepori: Čista stranka prava i panoramski pogled na 1903. godinu“. Časopis za suvremenu povijest, XXXVII, (2005), 609-623. 
- Matković, Stjepan. „Politički odnosi Josipa Franka i frankovaca prema radićevskoj ideologiji“. Radovi - Zavod za hrvatsku povijest, XXXII-XXXIII, br. 1, (2000), 277-283.

- Matković, Stjepan. „Prezreni pravaš - u prigodi 100. godišnjice smrti dr. Josipa Franka“. Pilar, XII, br. 2, (2011), 165-174.

- Matković, Stjepan. „Stranka prava i hrvatski kršćanski socijali“. U: Hrvatski katolički pokret. Urednik Zlatko Matijević, 321-330. Zagreb: Kršćanska sadašnjost, 2002.

- Matković, Stjepan. Čista stranka prava (1895-1903). Zagreb: Hrvatski institut za povijest, Dom i svijet, 2001.

- Matković, Stjepan. Izabrani portreti pravaša. Zagreb: Hrvatski institut za povijest, 2011.

- Mikavica, Dejan. Srpska politika u Hrvatskoj i Slavoniji: 1538-1918. Novi Sad: Filozofski fakultet, 2015.

- Miloradović, Goran. „Miroslav Krleža i pravaštvo. Prilog istoriji ideja i ideologija“. Istorija 20. veka, XXXVII, br. 2, (2019), 29-64. https://doi.org/10.29362/ist20veka.2019.2.mil.29-64

- Milošević, Srđan. „Istorijski revizionizam i društveni kontekst“. U: Politička upotreba prošlosti. Urednici: Momir Samardžić, Milivoj Bešlin i Srđan Milošević, 11-26. Novi Sad: Ako, 2013.

- Nikolić, Kosta. Prošlost bez istorije. Beograd: Institut za savremenu istoriju, 2003.

- Novak, Viktor. Magnum crimen - pola vijeka klerikalizma u Hrvatskoj. Zagreb: Nakladni zavod Hrvatske, 1948.

- Petrinović, Ivo. Politička misao Frana Supila. Split: Književni krug, 1988.

- Prelog, Milan. „Frank Josip Dr.“. U: Narodna enciklopedija Srpsko-hrvatskoslovenačka, I, A-H, 691. Zagreb: Zaklada tiskare narodnih novina, 1925.

- Radenić, Andrija. „Marginalije na Povijest hrvatskog naroda“. Istorijski glasnik, br. 1-2, (1969), 87-108.

- Radić, Stjepan. Frankova politička smrt (Izvješće o glavnoj razpravi u tiskovnoj parnici proti uredniku „Doma“). Zagreb: Hrvatska pučka seljačka tiskara, 1908.

- Skerlić, Jovan. Pisci i knjige. Beograd: Prosveta, 1956.

- Stančić, Nikša. Hrvatska nacija i nacionalizam u 19. i 20. stoljeću. Zagreb: Barbat, 2002.

- Starčević, Ante. „Dru. Josipu Franku, Sisak 5.8.1893.“. U: Ante Starčević, Izabrani spisi. Priredio Blaž Jurišić, 395-401. Zagreb: Hrvatsko izdavalačko bibliografski zavod, 1943.

- Strčić, Petar. „Zašto M. Ekmečić nije pobio niti jednu od mojih 49 primjedbi?““. Jugoslovenski istorijski časopis, br. 1-2, (1975), 183-184.

- Strecha, Mario. Katoličko pravaštvo: politički katolicizam u Banskoj Hrvatskoj u predvečerje Prvoga svjetskog rata: (1904-1910). Zagreb: Srednja Europa, 2011.

- Šegvić, Kerubin. Dr. Ante Starčević - njegov život i njegova djela. Zagreb: Tiskara Hrvatske stranke prava, 1911. 
- Šidak Jaroslav, Mirjana Gros, Igor Karaman i Dragovan Šepić. Povijest hrvatskog naroda g 1860-1914. Zagreb: Školska knjiga, 1968.

- Štih, Peter. „Revizija povijesti i revizionizam u historiografiji? Svakako!“‘. Scrinia Slavonica, XIX, br. 1, (2019), 375-381.

- Todorova, Marija. Imaginarni Balkan. Beograd: Biblioteka XX vek, 1999.

- Trifković, Srđa. Ustaše - balkansko srce tame. Beograd: Catena mundi, 2016.

- Trogrlić, Marko. „Hrvatska i „hrvatsko pitanje“ u korespondenciji Josipa Franka i Moritza von Auffenberg-Komarowa (1908.-1910.)“. U: Pravaška misao i politika. Urednici Jasna Turkalj, Zlatko Matijević, Stjepan Matković, 167-180. Zagreb: Hrvatski institut za povijest, 2007.

- Tuđman, Franjo. Bespuća povijesne zbiljnosti. Zagreb: Nakladni zavod Matice hrvatske, 1989.

- Turkalj, Jasna. Pravaški pokret 1878.-1887. Zagreb: Hrvatski institut za povijest, 2009.

- Vinaver, Stanislav. „Beograd i g. Krleža“. U: Zli volšebnici. Polemike i pamfleti u srpskoj književnosti 1917-1943. Knjiga prva 1917-1929. Urednik Gojko Tešić, 389-392. Beograd: Slovo ljubve, Beogradska knjiga, 1983.

- Vranicki, Predrag. Historija marksizma I. Zagreb: Naprijed, 1971. 
PETAR S. ĆURČIĆ, MA, Research Trainee

Institute for European Studies

Belgrade, Republic of Serbia

petar.pero.curcic@gmail.com

\section{JOSIP FRANK'S IMAGE IN CROATIAN HISTORIOGRAPHY: OVERVIEW OF PREVIOUS INTERPRETATIONS}

\section{Summary}

The aim of this work is to examine the interpretations of Josip Frank's political activity. Josip Frank (1844-1911) was a prominent turn of the century Croatian political figure and nationalist and liberal leader. As a controversial figure, his political ideas were thoroughly examined and evaluated in historiography through the last decades. There was no consensus among historians about his historical role. During the existence of Yugoslavia, the prevailing interpretations of Frank's political principles were mainly negative. The reason for these negative interpretations was Frank's anti-Serb ideology, which dominated his political discourse and as such was not viewed very favorable by Yugoslav historians. Not only this negative perception, but also a condemnation of memory was present in historiography. On one hand, it was caused by the views of his political opponents who had written several studies about Ante Starčević forgetting to mention Josip Frank. Actually, it was a peculiar struggle for domination whose final aspiration was a specific ideological and practical prevalence among pro-Starčević's Croatian politicians and voters. On the other hand, during the so-called Independent State of Croatia it was the result of the Ustasha regime's anti-Semitic policy. After the fall of communism and the breakup of Yugoslavia, a positive reception of Frank's significance inspired by a historical reevaluation of his role, as well as by political momentum (Croatian independence, war with Serbs etc.) became dominant in contemporary Croatian historiography.

KEYWORDS: Josip Frank, Historiography, Historiographic Paradigm, Interpretation of Past, Ideology 